Pinto, María; Caballero, David; Sales, Dora y Segura, Alicia (2020) “Belief in importance of information literacy abilities among undergraduates. Underlying factors and analysis of variance", Reference Services Review, Vol. ahead-of-print No. ahead-of-print.

Article first published online: July 8, 2020

DOI: https:/ / doi.org/10.1108/RSR-03-2020-0020

ISSN: 0090-7324

\title{
Belief in Importance of Information Literacy Abilities among Undergraduates. Underlying Factors and Analysis of Variance
}

\author{
María Pinto \\ Department of Information Science and Communication, \\ University of Granada, Granada, Spain \\ David Caballero \\ Department of Humanities and Social Sciences, \\ University of Granada, Granada, Spain \\ Dora Sales \\ Department of Translation and Communication, \\ University Jaume I, Castellon de la Plana, Spain \\ Alicia Segura \\ Department of Foreign Languages, \\ Auburn University, Auburn, Alabama, USA
}

\begin{abstract}
Purpose. The purpose of this paper is to analyse the levels of belief-inimportance of information literacy abilities (BILA) among an undergraduates' sample. The aim is, on the one hand, to discover if there is a representative latent structure, and, on the other hand, to know the existing differences according to external variables such as academic degree, course, gender and age.

Design/methodology/approach. A self-assessment questionnaire (ILHUMASS) was applied to a sample of 749 students in English Studies, Translation \& Interpreting, and Education in Spain. Three types of statistical methods have been used to study the results: descriptive, factorial, and analysis of variance.
\end{abstract}


Findings: Students' levels of BILA are acceptable but improvable. A framework of six underlying factors has been uncovered: evaluation-ethics, searching-using, technological processing, communication, dissemination, and cognitive processing of the information. Significant differences on degree, course and gender have been found.

Practical implications. This research is intended for a broad academic sector, including faculty, librarians and students in higher education. The BILA construct helps to improve the diagnosis of the perception of the belief in importance of information literacy abilities. Its representation through a reduced number of latent factors simplifies results and possible applications. The results show that variations in degree, course and gender are significant and should be taken into account.

Originality. Although much has been written about information literacy abilities we still know little about the importance students place on them. The BILA construct is intended to improve that knowledge.

Keywords: motivation, belief in importance, information literacy abilities, students learning, IL-HUMASS, factor analysis, analysis of variance.

Paper type: case study

\section{Introduction}

Over the last few decades, the amount of information available has progressively grown, as has its typology, in parallel with the emergence of new Information and Communications Technology (ICT) environments. Both circumstances make information access, processing and communication more sophisticated. Given its status as the raw material of learning, information management and communication are key issues in student learning and academic training. The primary objective in the 
disciplinary field of information literacy (IL) is precisely the improvement of the learning process as a whole. As stated by Riehle and Weiner (2013: 10-11), "though disciplines may refer to information literacy by different names [...] they are working toward the same learning goals."

Psychological aspects, and in particular motivational aspects, can also contribute to improving students' learning conditions. As stated by Maybee and Flierl (2016: 4), "thoughtfully crafted learning activities can produce little learning without students who are engaged and motivated." Students' academic success depends largely on their motivation to learn. Therefore a blended scaffolding, based on IL and motivation, should notably enhance students learning. There are numerous studies on motivation (Harlen and Crick, 2003; Law et al., 2010), but few address its relationship to information literacy abilities (ILA). Although motivation is a broad concept, this paper focuses on a single facet of motivation, the one related to belief in importance $(\mathrm{BI})$. As the creator of the belief-importance theory, Petrides $(2011: 161)$ states that: "personality traits confer on the individual a propensity to perceive convergences and divergences between their belief that they can attain goals and the importance that they place on these goals." The main objective of this research is to present the characteristics of the belief in importance of information literacy abilities (BILA) construct, as well as the results from a sample of students who completed the ILHUMASS self-assessment questionnaire. From our academic perspective, the knowledge of the motivational levels about BILA among administrators, teachers, librarians and students should be a starting point for future pedagogical actions.

The number of basic information abilities is considerable, highlighting search, evaluation, processing and communication skills (Pinto, 2010, 2011). From a pedagogical perspective, it is advisable to reduce this number of basic abilities to a smaller number of representative factors. It is also useful to know the variability of the 
sample, observing if there are significant differences among students in terms of degrees, courses, gender and age.

In the next section, we offer a review of the literature on BILA and the research questions that have driven this study.

\section{Literature review}

The literature review focuses on concepts related to the BILA construct, beliefin-importance $(\mathrm{BI})$ of IL abilities, in the academic fields of English Studies, Translation \& Interpreting and Education, to which the students of the analysed sample belong. We refer, on the one hand, to the convergence of $\mathrm{IL}$ and $\mathrm{BI}$, and, on the other hand, to their perception from these disciplines.

\section{Convergence of $I L$ and $B I$}

Information literacy (IL) has taken a great boost in the literature of the last few decades. Institutions and individuals are determined to define key IL topics (ACRL, 2000; ACRL, 2016). In fact, this research deals with all the issues involved in IL. Among them are those of searching (Rich, 2008; Ding and Ma, 2013; Rieh et al., 2016), evaluation (Hjørland, 2012), processing (Savolainen, 2009), ethics (Samek, 2010), communication (ACRL, 2013), technological processing (Markauskaite, 2007), and computer technology (Malliari, Korobili and Togia, 2012). In any case, IL abilities relate to both "declarative as well as procedural knowledge [since they] can be seen as predictor of competency" (Zylka, 2012: 778).

The abundance of literature on IL and its specific abilities contrasts with the few publications on BI. Librarians tend to assume that first-year students "have but a shallow understanding of the importance of information in their lives" (Seamans, 2002). In any case, a common belief among scholars is that motivation influences learning and vice-versa (Maybee and Flierl, 2016). According to Kraiger, Ford and Salas (1993: 
319), motivational variables are "indicators of learning, rather than simply precursors to learning." Considering the "constructivist nature of student learning and the mediational role of motivational and cognitive processes" (Pintrich, 2004: 388), any motivational impact will have its corresponding outcome on the cognitive side, that is, on learning outcomes. In this line, the growing development of game-based learning approaches stands out, with the aim of "incorporating these game mechanics [...] to motivate students to independently search for information that would enhance the students' learning outcomes" (Subhash and Cudney, 2018: 195).

As we will see, literature on the convergence of $\mathrm{BI}$ and $\mathrm{IL}$ is scarce. However, we have found within the IL literature some concepts that are similar to that of BI. Gross and Latham (2012: 575) care about the relationship "between IL skill level and other variables such as self-assessment of skill," a variable that is quite close to that of belief-in-importance of IL abilities that leads this work. The concept of value making reflections about the value of new knowledge- is used by Guglietti (2015: 4) since it, as with BI, "may help explain why some pedagogies and strategies either succeed or fail." Maybee and Flierl (2016) refer to "perceived competence, an aspect of motivation [that] has been associated with an internalized interest in research and better performance on information literacy skills test." Ross, Perkins and Bodey (2016: 3) underline the fact that "numerous studies have highlighted the importance of motivation to academic achievement and performance [...] and to the acquisition of IL skills." More recently, Rosman et al. (2018) use the concept of "epistemic beliefs" to reflect on the value of knowledge in relation to IL. Their perspective presents some affinities with the approach we have taken in this study, when dealing with the intrinsic motivation in learning, the ethical value of knowledge and the use of information. 


\section{IL and BI from the disciplines}

The prominence of discipline issues in IL environments is a key aspect: "imparting IL skills to students involves equipping them with knowledge about the subject-specific content and research practices of particular disciplines" (Grafstein, 2002: 197). A number of publications relate IL to the disciplines (Bury, 2011; Kuglitsch, 2015), but few of them address both motivation and IL abilities from a disciplinary approach. According to Oakleaf, Millet and Kraus (2011: 832), "Information literacy skills $[\ldots]$ are crucial for learning across all academic disciplines and higher education environments". And for Farrell and Badke (2015: 319), "a socio-cultural understanding of learning allows educators to view academic disciplines as unique cultures that include unique information practices."

In relation to the degrees covered in this paper, with regard to English Studies, Swenson et al. (2006: 351) focused on the "multimodal literacies and digital technologies" that influence this discipline. Webber, Boon and Johnston (2005: 7-8) uncovered four qualitatively different features of IL, depending on the context, time period, or particular media with which IL is associated. Interest in informational issues also affects students in English composition, "but they tend to do research superficially" (Holliday and Fagerheim, 2006: 171). To date, we have not found publications on the motivation of English Studies students towards IL abilities.

Regarding the study of Translation \& Interpreting, Pinto and Sales (2010: 628) tackled the topic of students' BILA, evidencing the need for highlighting the least valued abilities. These diagnosed weak abilities belonging to "the technical section of the information-processing category". Massey and Ehrensberger-Dow (2011: 208), grounding on a qualitative and phenomenological perspective, concluded that: "although the development of information literacy can be considered a key aspect in 
the acquisition of translation competence [...] is only now emerging as a significant area of research in Translation Studies."

In this same way, Education studies place IL at the centre of many general education programs as an "enabler for continuous learning in a technologically rich and globally diverse society" (Rockman, 2002: 187-195). Likewise, Mills et al. (2014: 326) highlighted the relationship between attitudes towards IL and the preference for ICT and mobile learning. To date, no specific publications about BILA have been found in the field of Education. In fact, some studies such as those carried out by Lim and Huan (2017) or Baier et al. (2019), propose an approach, but only refer to the intersection between both elements (BILA) in an indirect way, and do not focus on the university population.

According to the above, we assume that there is a positive relationship between students' levels of BILA and their impact on learning. Based on this starting assumption, the present study pursues specific answers to the following research questions:

RQ1. What are the levels of belief-in-the-importance of a series of key information literacy abilities (BILA) among undergraduates?

RQ2. Concerning this set of perceived abilities, may they be adequately represented by a fewer number of underlying, or latent, abilities? Which ones?

RQ3. Are there non-random differences in BILA's perceptions depending on contextual variables such as degree, course, gender, or age?

This case study is limited to the context of Spanish Higher Education. It has been developed with the collaboration of teaching faculty and the contribution of undergraduates on English Studies, Translation \& Interpreting, and Education. 


\section{Material and methods}

\section{The sample}

For this study, the population was defined on the basis of statistical data from the Annual Reports of Spanish universities (University of Granada and Jaume I University). It is comprised of students enrolled in English Studies, Translation \& Interpreting, and Education degrees in the 2017 academic year in both institutions. The universe for the study was made up of a total of 1372 students from these three degrees: English Studies (385 students), Translation \& Interpreting (469 students) and Education (518 students). A stratified sampling process with proportional allocation ensures the representativeness of the information gathered. It also allows inferences to be made with an appropriate level of consistency. The number of participants was 775 , and the final sample amounted to 749 students, as twenty-six incomplete questionnaires were dismissed. The characteristics of the sample (age, gender, course, and degree), including frequencies and ratios, are detailed in Table 1.

\begin{tabular}{|l|lcc}
\multicolumn{1}{c}{} & Frequency & $\%$ \\
\hline \multirow{2}{*}{ Gender } & Men & 175 & 23.40 \\
& Women & 574 & 76.60 \\
\hline \multirow{2}{*}{ Course } & Junior & 628 & 83.80 \\
& Senior & 121 & 16.20 \\
\hline \multirow{3}{*}{ Degree } & English Studies & 195 & 26.00 \\
& Translation & 231 & 30.80 \\
& Education & 323 & 43.10 \\
\hline \multirow{2}{*}{ Age } & $\leq 25$ & 692 & 92.40 \\
& $\geq 25$ & 57 & 7.60 \\
\hline \multirow{2}{*}{} & Total & 749 & 100.00
\end{tabular}

Table 1. Students' frequency according to age, gender, course, and degree. 


\section{Tools and procedures}

According to Linnenbrink and Pintrich (2002: 313-314), "students' own thoughts about their motivation and learning play a key role in mediating their engagement and subsequent achievement". IL-HUMASS self-assessment questionnaire echoes this key role (Pinto, 2010; 2011). Composed of twenty-six items and clustered into four categories -searching, evaluation, processing, and communication of the information-, it assembles three subjective scales -belief in importance (BI), self-efficacy (SE), and preferred sources of learning (LS)- (see Annex). However, the analysis presented here is limited to the first one (Annex), that is, belief in importance $(\mathrm{BI})$. One-to-nine Likert scale is employed: $\leq 5$ (not any), 5-6 (scarce), 6-7 (moderate), 7-8 (high), $\geq 8$ (excellent). Survey implementation was completed online, mostly in computer lab. With consent from teaching faculty and institutional heads, we provided the students with an explanation of the research goals.

Three types of statistical analysis have been performed to study the results: descriptive, factorial, and analysis of variance. Statistical descriptive analysis pursues the knowledge of BILA's mean scores and their distribution depending on degree, course, gender, and age in each of the IL abilities.

One of the main goals of this research is uncovering the structure that represents -using a reduced number of factors- the set of twenty-six competencies of the IL-HUMASS survey. For this, we have drawn upon the acknowledged statistical technique of factor analysis, whose main objective is to summarize data for the better interpretation and understanding of relationships and patterns. Factor analysis "operates on the notion that measurable and observable variables can be reduced to fewer latent variables that share a common variance and are unobservable" (Yong and Pearce, 2013: 80). This reduction of dimensionality would contribute to a better 
understanding of the deep factors involved in the $\mathrm{BI}$ dimension, thus easing any pedagogical approach. Basic steps in factor analysis are the choice of the extraction and rotation methods. In this regard, specific methods of extraction -principal component analysis- and rotation -Varimax with Kaiser normalization- have been used (DeCoster, 1998; Taylor, 2001).

However, if we are looking for a better understanding of students' status concerning the $\mathrm{BI}$ dimension, we should also explore the likely differences between groups in different student's contexts: degree, course, gender, and age. It is especially interesting to know the competencies in which statistically significant differences between these groups of students arise. This would allow us to accurately determine some motivational initiatives addressed to the groups of more-in-need students. In practice, we have identified this significant variability using the appropriate analysis of variance, deploying t-test and ANOVA. While the former is useful to compare courses juniors versus seniors- and gender -men versus women-, the later allows exploration of BILA's differences among students of the three involved degrees -English Studies, Translation \& Interpreting, Education-. The null hypothesis employed here presupposes that the relationship between variables of different groups is due exclusively to chance, thus not being statistically significant. Conversely, relationships are significant when not due to chance (Keselman et al., 1998). For all the statistical analyses, the IBM SPSS 22 statistical program has been used.

\section{Results}

The sample shows high levels of reliability or internal consistency (Cronbach's alpha coefficient $=0.930$ ). All competencies correlate moderately -between 0.3 and 0.7- being significant at 0.01 levels. Besides, data deviate from a normal distribution (Kolmogorov-Smirnov and Shapiro-Wilk tests: sig. $=0.000)$. Though students' levels of 
$\mathrm{BI}$ are "high" in most competencies, there is room for improvement. The descriptive analysis uncovers the actual levels of BILA among students.

\begin{tabular}{|c|c|c|c|c|c|c|c|c|c|}
\hline \multirow{3}{*}{$\begin{array}{l}\text { Belief in the Importance of IL abilities } \\
\text { (BILA) }\end{array}$} & \multicolumn{7}{|c|}{ Mean values } & \multirow{2}{*}{\multicolumn{2}{|c|}{ Global }} \\
\hline & \multicolumn{3}{|c|}{ Degree } & \multicolumn{2}{|c|}{ Course } & \multicolumn{2}{|c|}{ Gender } & & \\
\hline & ES & TR & ED & 3 & 4 & M & $\mathrm{F}$ & Mean & $\begin{array}{c}\text { St. } \\
\text { Dev. }\end{array}$ \\
\hline Use printed sources & 7,83 & 7,77 & 7,95 & 7,9 & 7,67 & 7,85 & 7,86 & 7,86 & 1,252 \\
\hline Use automated catalogues & 7,01 & 7,11 & 6,98 & 7,04 & + 6,99 & 7,12 & 7 & 7,03 & 1,536 \\
\hline Use electronic sources of primary information & 7,66 & 7,67 & 7,85 & 7,75 & 7,73 & 7,77 & 7,74 & 7,75 & 1,224 \\
\hline Use electronic sources of secondary information & 7,26 & 7,53 & 7,46 & 7,45 & 7,32 & 7,47 & 7,41 & 7,43 & 1,420 \\
\hline Know terminology of the subject & 7,86 & 8,09 & 7,21 & 8,11 & 7,91 & 8,06 & 8,09 & 8,08 & 1,189 \\
\hline Search and retrieval Internet information & 7,91 & 8,14 & 7,96 & 8 & 8,06 & 8,01 & 8 & 8,01 & 1,111 \\
\hline Use informal electronic sources of information & 7,14 & 6,98 & 7,55 & 7,29 & 7,16 & 7,11 & 7,31 & 7,27 & 1,364 \\
\hline Know information search strategies & 6,77 & 6,68 & 6,93 & 6,84 & $+6,65$ & 6,73 & 6,83 & 6,81 & 1,658 \\
\hline Assess quality of information resources & 7,82 & 8,16 & 8,11 & 8,08 & 7,87 & 8,08 & 8,04 & 8,05 & 1,118 \\
\hline Recognize author's ideas & 8,06 & 8,23 & 8,38 & 8,29 & 8,06 & 8,2 & 8,26 & 8,25 & ,989 \\
\hline Know typology of scientific information sources & 7,03 & 7,25 & 7,26 & 7,23 & 7,04 & 7,14 & 7,22 & 7,20 & 1,504 \\
\hline Determine whether information is updated & 7,64 & 7,94 & 8,02 & 7,96 & 7,6 & 7,75 & 7,94 & 7,90 & 1,291 \\
\hline Know most relevant authors-institutions & 7,65 & 7,94 & 7,79 & 7,84 & 7,59 & 7,64 & 7,85 & 7,80 & 1,295 \\
\hline Schematize-abstracting of information & 8,44 & 8,23 & 8,58 & 8,48 & 8,19 & 8,32 & 8,47 & 8,43 & 860 \\
\hline Recognize text structure & 7,84 & 7,66 & 8,05 & 7,89 & 7,78 & 7,79 & 7,9 & 7,88 & 1,083 \\
\hline Use database managers & 6,97 & 6,61 & 7,15 & 6,99 & 6,67 & 6,63 & 7,03 & 6,94 & 1,709 \\
\hline Use bibliographic reference managers & 6,68 & 6,53 & 6,8 & 6,77 & 6,26 & 6,39 & 6,77 & 6,68 & 1,691 \\
\hline Handle statistical programs and spreadsheets & 7,06 & 6,95 & 7,5 & 7,25 & 7,02 & 6,93 & 7,3 & 7,22 & 1,631 \\
\hline Install computers programs & 7,27 & 7,71 & 7,63 & 7,63 & 7,21 & 7,22 & 7,66 & 7,56 & 1,602 \\
\hline Communicate in public & 8,46 & 8,51 & 8,6 & 8,56 & 8,42 & 8,57 & 8,53 & 8,54 & ,905 \\
\hline Communicate in other languages & 7,95 & 8,24 & 8,33 & 8,25 & 7,95 & 8,32 & 8,17 & 8,20 & 1,424 \\
\hline Write a document & 8,34 & 8,52 & 8,56 & 8,51 & 8,4 & 8,53 & 8,48 & 8,49 & ,846 \\
\hline Know the code of ethic in your field & 7,93 & 7,81 & 8,13 & 7,98 & 7,94 & 7,85 & 8,02 & 7,98 & 1,260 \\
\hline Know laws on use of information and property & 7,5 & 7,91 & 7,56 & 7,71 & 7,38 & 7,59 & 7,68 & 7,66 & 1,437 \\
\hline Create academic presentations & 8,02 & 7,93 & 8,32 & 8,19 & 7,75 & 7,92 & 8,18 & 8,12 & 1,253 \\
\hline Disseminate information on the Internet & 7,81 & 8,01 & 8,05 & 8,03 & 7,71 & 7,81 & 8,02 & 7,97 & 1,177 \\
\hline
\end{tabular}

Degree (ES) English Studies (TR) Translation (ED) Education

Course (3_4) Juniors - Seniors

Gender (M-F) Male-Female 
Table 2. BILA's mean scores by degree, course and gender. Note: Age is not included because it has been shown not to be a significant variable in this sample.

Overall, BILA's mean scores are "high" (7.72). The four abilities with higher mean scores are communicate in public (20), write a document (22), schematizeabstracting information (14), and recognize author's ideas (10); the four lowest scores are assigned to use automated catalogues (2), use database managers (16), know information search strategies (8) and use bibliographic reference managers (17). Nine abilities rate as "excellent", fourteen "high", and three "moderate". Lower scores are for students of English Studies, highest for Education (Table 2).

\section{Underlying factors}

To uncover the essentials of the BILA construct, the factor analysis technique provided six factors, explaining a significant amount of variance $(64.05 \%)$. The analysis accomplishes KMO measure of sample adequacy $(0,933)$ and Bartlett sphericity $(\operatorname{sig}=0,000)$ tests. The factor loading of the different skills is shown. Ordered by weight -variance explained- the factors are the following: evaluation-ethics, searching-using, technological processing, communication, dissemination, and cognitive processing of the information (Table 2). These factors are consistent with the four IL-HUMASS categories -search, assessment, processing, and communication. The processing category is displayed in the factors of technological processing and cognitive processing. Likewise, the communication category unfolds into the factors of communication and dissemination. In any case, these six factors are linearly independent. 
Rotated component matrix a

\begin{tabular}{|c|c|c|c|c|c|c|c|c|c|c|}
\hline \multicolumn{3}{|c|}{$\begin{array}{l}\text { Belief in Importance of IL abilities } \\
\text { (BILA) }\end{array}$} & \multicolumn{6}{|c|}{ Component } & \multirow[b]{2}{*}{ Mean } & \multirow[b]{2}{*}{$\begin{array}{l}\text { St. } \\
\text { Dev. }\end{array}$} \\
\hline Factor & $n$ & Abilities & 1 & 2 & 3 & 4 & 5 & 6 & & \\
\hline \multirow{8}{*}{$\begin{array}{l}\text { Evaluation and } \\
\text { ethics }\end{array}$} & 12 & \begin{tabular}{|l|} 
Determine whether \\
information is updated
\end{tabular} & 0,693 & & & & & & 7,90 & 1,291 \\
\hline & 10 & $\begin{array}{l}\text { Recognize author's } \\
\text { ideas }\end{array}$ & 0,676 & & & & & & 8,25 & ,989 \\
\hline & 9 & $\begin{array}{l}\text { Assess quality of } \\
\text { information resources }\end{array}$ & 0,650 & & & & & & 8,05 & 1,118 \\
\hline & 13 & $\begin{array}{l}\text { Know most relevant } \\
\text { authors-institutions }\end{array}$ & 0,645 & & & & & & 7,80 & 1,295 \\
\hline & 11 & $\begin{array}{l}\text { Know typology of } \\
\text { scientific information } \\
\text { sources }\end{array}$ & 0,621 & & & & & & 7,20 & 1,504 \\
\hline & 24 & $\begin{array}{l}\text { Know laws on use of } \\
\text { information and } \\
\text { property }\end{array}$ & 0,534 & & & & & & 7,66 & 1,437 \\
\hline & 5 & $\begin{array}{l}\text { Know terminology of } \\
\text { the subject }\end{array}$ & 0,525 & & & & & & 8,08 & 1,189 \\
\hline & 23 & $\begin{array}{l}\text { Know the code of } \\
\text { ethic in your field }\end{array}$ & 0,505 & & & & & & 7,98 & 1,260 \\
\hline \multirow{6}{*}{$\begin{array}{l}\text { Searching and } \\
\text { use }\end{array}$} & 3 & \multirow{6}{*}{$\begin{array}{l}\text { Use electronic } \\
\text { sources of primary } \\
\text { information } \\
\text { Use electronic } \\
\text { sources of secondary } \\
\text { information } \\
\text { Use automated } \\
\text { catalogues } \\
\text { Use printed sources } \\
\text { Search and retrieval } \\
\text { Internet information } \\
\text { Use informal } \\
\text { electronic sources of } \\
\text { information } \\
\end{array}$} & & 0,757 & & & & & 7,75 & 1,224 \\
\hline & 4 & & & 0,671 & & & & & 7,43 & 1,420 \\
\hline & 2 & & & 0,627 & & & & & 7,03 & 1,536 \\
\hline & 1 & & & 0,626 & & & & & 7,86 & 1,252 \\
\hline & 6 & & & 0,567 & & & & & 8,01 & 1,111 \\
\hline & 7 & & & 0,429 & & & & & 7,27 & 1,364 \\
\hline \multirow{4}{*}{$\begin{array}{l}\text { Technological } \\
\text { processing }\end{array}$} & 16 & \begin{tabular}{|l|} 
Use database \\
managers
\end{tabular} & & & 0,817 & & & & 6,94 & 1,709 \\
\hline & 17 & $\begin{array}{l}\text { Use bibliographic } \\
\text { reference managers }\end{array}$ & & & 0,779 & & & & 6,68 & 1,691 \\
\hline & 18 & $\begin{array}{l}\text { Handle statistical } \\
\text { programs and } \\
\text { spreadsheets }\end{array}$ & & & 0,591 & & & & 7,22 & 1,631 \\
\hline & 8 & $\begin{array}{l}\text { Know information } \\
\text { search strategies }\end{array}$ & & & 0,539 & & & & 6,81 & 1,658 \\
\hline \multirow{3}{*}{ Communication } & 20 & $\begin{array}{l}\text { Communicate in } \\
\text { public }\end{array}$ & & & & 0,806 & & & 8,54 & ,905 \\
\hline & 21 & $\begin{array}{l}\text { Communicate in other } \\
\text { languages }\end{array}$ & & & & 0,789 & & & 8,20 & 1,424 \\
\hline & 22 & Write a document & & & & 0,656 & & & 8,49 & 846 \\
\hline \multirow{3}{*}{ Dissemination } & 26 & $\begin{array}{l}\text { Disseminate } \\
\text { information on the } \\
\text { Internet }\end{array}$ & & & & & 0,790 & & 7,97 & 1,177 \\
\hline & 19 & $\begin{array}{l}\text { Install computers } \\
\text { programs }\end{array}$ & & & & & 0,652 & & 7,56 & 1,602 \\
\hline & 25 & $\begin{array}{l}\text { Create academic } \\
\text { presentations }\end{array}$ & & & & & 0,592 & & 8,12 & 1,253 \\
\hline \multirow[b]{2}{*}{$\begin{array}{l}\text { Cognitive } \\
\text { processing }\end{array}$} & 15 & $\begin{array}{l}\text { Recognize text } \\
\text { structure }\end{array}$ & & & & & & 0,683 & 7,88 & 1,083 \\
\hline & 14 & $\begin{array}{l}\text { Schematize- } \\
\text { abstracting of } \\
\text { information }\end{array}$ & & & & & & 0,630 & 8,43 & ,860 \\
\hline
\end{tabular}




\begin{tabular}{|c|c|c|c|c|c|c|}
\hline Explained variance \% & 15,00 & 12,46 & 11,51 & 10,48 & 9,25 & 6,45 \\
\hline Mean values & 7,87 & 7,56 & 6,91 & 8,41 & 7,88 & 8,16 \\
\hline Standard deviation & 1,260 & 1,318 & 1,672 & 1,058 & 1,344 & 0,972 \\
\hline
\end{tabular}

Table 3. BILA's six underlying factors.

\section{Evaluation and ethics of information}

This is the most important factor since it explains the higher rate of variance (15.00\%). It gathers eight IL abilities, related to assessment and ethics. In factor analysis, the relationship of each variable to the underlying factor is expressed by the so-called factor loading. In this sense, ranked by factor loading, the abilities in this cluster are the following: determine whether the information is updated; recognize author's ideas; assess the quality of information resources; know most relevant authors-institutions; know the typology of scientific information sources; know laws on the use of information and intellectual property; know the terminology of the subject; and know the code of ethics in your field.

\section{Searching and using of information}

This factor clusters six IL abilities, focused on information search and use (explained variance $=12.46 \%$ ). Ranked by factor loading, the abilities in this group are: use of electronic sources of primary information; use of electronic sources of secondary information; use of automated catalogues; use of printed sources; search and retrieval of internet information; and use of informal electronic sources of information. 


\section{Technological processing of information}

This factor refers to the set of skills related to information technology management. Its weight is significant $(11.51 \%)$. The competencies that make up this group, ranked by factor loading, are the following: use database managers; use bibliographic reference managers; handle statistical programs and spreadsheets; and know information search strategies. This factor is distinguished by its low average values and high dispersion. In fact, this factor offers the lowest mean score (6.91) and the highest standard deviation (1.672).

\section{Communication of information}

This factor groups the following three skills, related to key aspects of academic communication: communicate in public; communicate in other languages; and writing a document (explained variance $=10,48 \%$ ). It offers excellent perceived scores $(8.41)$, as well as a low standard deviation (1.058).

\section{Dissemination of information}

Factor five on information dissemination depends on three abilities. Ranked by factor loading, these are: disseminate information on the Internet, install computer programs, and creating academic presentations (explained variance $=9,25 \%$ ).

\section{Cognitive processing of information}

Factor six on cognitive processing depends on two abilities: recognize texts structure as well as schematizing-abstracting information. Although this factor explains the lower percentage of variance $(6.45 \%)$, it provides an excellent observed score (8.16) and the lowest standard deviation (0.972). 


\section{Non-random variations}

As previously stated, a better understanding of how a series of contextual factors such as degree, course, gender, and age influence students' BILA perceptions is needed. After the application of t-test and ANOVA statistics, we have found that age is the only variable that does not depict any significant difference. Regarding the other variables (degree, course and gender), non-random variations are more or less salient in a sizeable number of abilities (Table 4).

The application of ANOVA methods to English Studies, Translation \& Interpreting and Education students allows us to uncover a number of significant differences when comparing BILA's mean values. In the case of the pair English Studies and Translation \& Interpreting, significant differences emerge in eleven competencies. They belong to the factors of evaluation and ethics (5), searching and use (1), technological processing (1), communication (2), dissemination (1), and cognitive processing (1). Translation \& Interpreting students scored the highest. Similarly, when we compare English Studies and Education students, statistically significant differences emerge in twelve from the twenty-six items. They belong to the factors of evaluation and ethics (4), searching and use (1), technological processing (1), communication (2), dissemination (3), and cognitive processing (1). In this case, the best means belonged to Education students. Comparing Translation \& Interpreting and Education students, significant differences amount to eight. These appear in the factors of evaluation and ethics (2), searching and use (1), technological processing (2), dissemination (1), and cognitive processing (2). With some exceptions, the higher values belong to Education students. No competence showed significant differences in all three pairings. On the other hand, eight items did not show significant BI's differences in any of the three pairings (Table 4). In summary, the higher number of lowest mean scores in the abilities in which significant differences appear refer to English Studies, since this circumstance occurs in fifteen competences; seven in the 
the degree, no differences arise in seven abilities (Table 4).

\begin{tabular}{|c|c|c|c|c|c|c|c|}
\hline \multirow{2}{*}{\multicolumn{3}{|c|}{ Belief in the importance of IL abilities (BILA) }} & \multicolumn{5}{|c|}{ Significant differences of the means } \\
\hline & & & \multicolumn{3}{|c|}{ Degree } & \multirow{2}{*}{\begin{tabular}{|c|} 
Course \\
$3 \_4$
\end{tabular}} & \multirow{2}{*}{$\frac{\text { Gender }}{\text { M_F }}$} \\
\hline Factor & $\mathrm{n}$ & Abilities & ES_TR & ES_ED & TR_ED & & \\
\hline \multirow{8}{*}{ Evaluation and ethics } & 12 & \multirow{8}{*}{$\begin{array}{l}\text { Determine whether information is } \\
\text { updated } \\
\text { Recognize author's ideas } \\
\text { Assess quality of information } \\
\text { resources } \\
\text { Know most relevant authors- } \\
\text { institutions } \\
\text { Know typology of scientific } \\
\text { information sources } \\
\text { Know laws on use of information } \\
\text { and property } \\
\text { Know terminology of the subject } \\
\text { Know the code of ethic in your } \\
\text { field }\end{array}$} & 016 & 001 & & 005 & \\
\hline & 10 & & &, 000 & &, 020 & \\
\hline & 9 & & ,001 & ,004 & & & \\
\hline & 13 & & 022 & & & ,050 & \\
\hline & 11 & & & & & & \\
\hline & 24 & & ,003 & &, 005 & ,021 & \\
\hline & 5 & & ,046 & ,001 & & & \\
\hline & 23 & & & & ,003 & & \\
\hline \multirow{5}{*}{ Searching and use } & $\begin{array}{l}3 \\
4\end{array}$ & $\begin{array}{l}\text { Use electronic sources of primary } \\
\text { information } \\
\text { Use electronic sources of } \\
\text { secondary information }\end{array}$ & & & & & \\
\hline & 2 & Use automated catalogues & & & & & \\
\hline & 1 & Use printed sources & & & & & \\
\hline & 6 & $\begin{array}{l}\text { Search and retrieval Internet } \\
\text { information }\end{array}$ & ,033 & & & & \\
\hline & 7 & $\begin{array}{l}\text { Use informal electronic sources of } \\
\text { information }\end{array}$ & &, 001 &, 000 & & \\
\hline \multirow{3}{*}{$\begin{array}{l}\text { Technological } \\
\text { processing }\end{array}$} & 16 & Use database managers & ,032 & & ,000 & & ,008 \\
\hline & 17 & $\begin{array}{l}\text { Use bibliographic reference } \\
\text { managers }\end{array}$ & & & & ,002 & ,008 \\
\hline & $\begin{array}{l}18 \\
8\end{array}$ & $\begin{array}{l}\text { Handle statistical programs and } \\
\text { spreadsheets } \\
\text { Know information search } \\
\text { strategies }\end{array}$ & & ,003 &, 000 & & ,008 \\
\hline \multirow{3}{*}{ Communication } & 20 & Communicate in public & & & & & \\
\hline & 21 & Communicate in other languages & ,033 & ,003 & & ,033 & \\
\hline & 22 & Write a document & ,032 &, 004 & & & \\
\hline \multirow{3}{*}{ Dissemination } & 26 & $\begin{array}{l}\text { Disseminate information on the } \\
\text { Internet }\end{array}$ & & 022 & &, 007 & ,036 \\
\hline & 19 & Install computers programs & ,004 & ,013 & & ,010 & ,001 \\
\hline & 25 & Create academic presentations & & ,009 &, 000 &, 000 &, 016 \\
\hline \multirow[b]{2}{*}{ Cognitive processing } & 15 & Recognize text structure & & 026 &, 000 & & \\
\hline & 14 & $\begin{array}{l}\text { Schematize-abstracting of } \\
\text { information }\end{array}$ & ,011 & &, 000 & ,001 & ,048 \\
\hline
\end{tabular}

Degree (ES) English Studies (TR) Translation (ED) Education

Course (3_4) Juniors - Seniors

Gender (M_F) Male-Female 
Table 4. Significant differences in degree, course, and gender.

Comparisons between junior and senior students involve ten of the abilities. Juniors obtained the highest scores. The non-random differences mainly affect factors one -evaluation/ethics- and five -dissemination-. If we take into account gender, only seven abilities prove significant differences. Most of them relate to factors three technical processing- and five -dissemination-; mean scores are higher regarding female students. Concerning course and gender, no differences arise in fourteen abilities (Table 4).

\section{Discussion}

First, the role of the factors discovered will be addressed, ordered by their relative importance, and their possibilities in the improvement of the BILA levels among the students. Secondly, we will address the possible sources of variability, such as degree, course and gender. Finally, some initiatives for the motivational improvement of students will be suggested.

\section{On the uncovered factors}

From a latent perspective, the results differ significantly compared to the observed values. It is precisely the three most important factors that offer the lowest values. On the other hand, the three lightest factors have the highest values (Figure 1). In any case, reducing the twenty-six information skills to six factors simplifies the approach to motivation in learning information skills. These underlying factors, which are independent of each other, make it possible to design a plan for improving student motivation for each of them. While some are preferably declarative, based on knowledge, others are procedural, focused on the use of information and 
communication technologies (ICT) (Zylka, 2012). Ultimately, general cognitive and technological aspects "cannot be developed separately" (Markauskaite, 2007: 552). It can be seen how the factorial configuration matches with the categories proposed in the questionnaire. But the processing and communication categories are divided into two factors each (Table 3).

The factor on evaluation and ethics of the information, with the higher weight, relates to the theoretical side of $\mathrm{IL}$, and more specifically to the knowledge of the concepts of information evaluation and ethics. Evaluation is a mental, cognitive, subjective and complex activity, in which factors such as intuition, reasoning, context, personal background or information needs intervene (Mai, 2013). The challenge for IL programs is how to teach students to make sense of the vast amount of information they find every day on the Internet, to identify credible sources, to evaluate the reliability and validity of what they read, and to question the authenticity and accuracy of the information (UNESCO, 2015: 41). Therefore, the need for critical evaluation of information is a common denominator in all circumstances (Schield, 2004; Limberg et al., 2008; Saeger, 2014). Students need a better understanding of the criteria related to certain indicators in order to evaluate the quality of information sources, such as, among others, reliability, authorship, credibility of the publication source, relevance of the information or content updating (Metzger, 2007; McClure and Clink, 2009: 117; Hjørland, 2012). This factor also incorporates cognitive skills in relation to information ethics, a subject whose literature is abundant, although the perspectives from which it is dealt with are often more abstract (Koehler and Pemberton, 2000; Carbo and Almagno, 2001; Budd, 2006; Fallis, 2007; Liu and Yang, 2012; Paul, 2013; Floridi, 2013). In this eminently declarative factor, a high number of significant differences arise. They are greater in the comparison between degrees, lower in courses, and null in gender. This high percentage of variability responds to the detected instructional deficiencies. 
The factor concerning information searching and using is quite broad in scope. The concepts of information searching and using, although related, are different. Since its inception (Kuhlthau, 1991), research on information searching has been a permanent topic in the literature on IL (Gross and Latham, 2008; Rich, 2008; Ding and Ma, 2013; Leichner et al., 2014; Rieh et al., 2016; Savolainen, 2018). There are other related concepts, such a user, user need, and seeking behaviour (Wilson, 2008; Subhash Reddy, Krishnamurthy and Asundi, 2018). With a mostly procedural aim, this factor is oriented towards skills related to the search for and use of both printed and electronic information resources, whether primary, secondary, or informal. Its high weight as a factor contrasts with the low average value that students assign to the skills that make up this factor (Figure 1). Non-random differences are scarce concerning degree, involving only two abilities, and null regarding course and gender.

The factor of technological processing is primarily concerned with the management of databases and bibliographical references. For Jones (2007: 453), personal information management "places special emphasis on the organization and maintenance of personal information collections." This is a rather procedural factor. Given its high weight as a latent factor and its low values observed, it must be taken into account in order to improve student learning. Significant differences are few in degree's comparison, minimum in course, and abundant in gender.

The factor of communication mainly addresses academic environments. Nonrandom differences affect English Studies students, being symbolic in relation to course, and null regarding gender. Meanwhile, the dissemination factor refers not only to the Internet in a generic way but also, and more specifically, to the presentation of information in academic environments. Concerning degree, the significant differences mainly refer to students of English Studies and of Education. As for course and gender, all abilities are involved. In any case, these two factors (communication and dissemination) are closely related (Davis-Kahl, 2012; Davis-Kahl and Hensley, 2013). 
As García-Marco (2017) put forward, from the viewpoint of the knowledge creation and sharing cycle, communicative competence plays an essential role in academic settings. Moreover, due to its transversal relevance, communication-dissemination is an increasingly important field of action and practice for the instructional design of IL programs. Last, the factor of cognitive processing has a double function: active in relation to the tasks of outlining and summarizing information; and passive, with regard to the ability to recognize such structures.

We have been able to check the balance between declarative and procedural factors. The most important one -evaluation and ethics of the information- is strongly declarative. This means that students give priority to knowledge of concepts related to information evaluation and ethics. Ultimately, one of the key features of the factors is that they are statistically independent. They should be addressed separately without mutual incidence. The reduction of twenty-six abilities to six factors eases any approach to BILA.

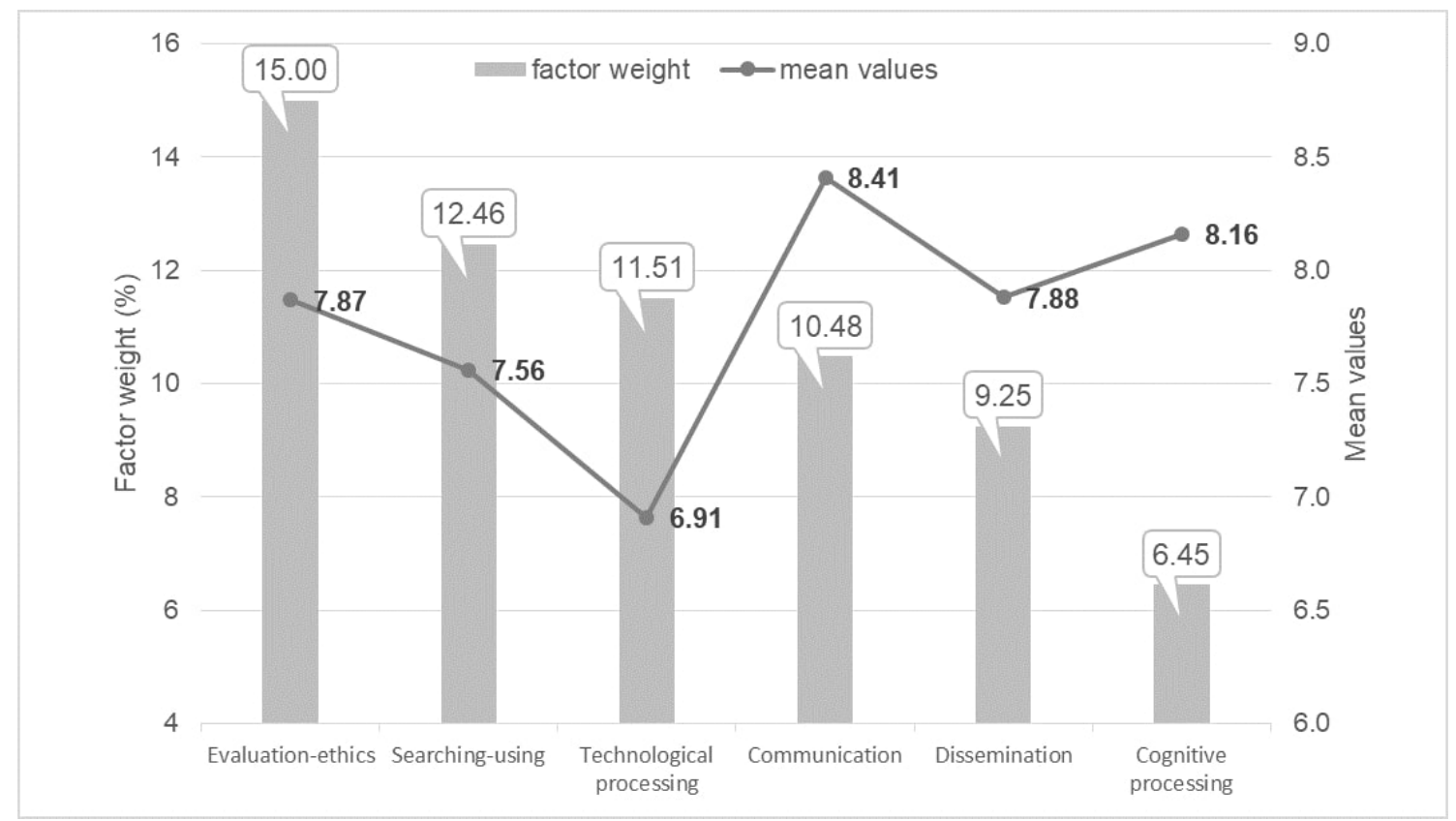


Figure 1. Divergences between BILA's latent factor weights and observed mean values.

The greatest opportunities for enhancement arise in the first three factors, as they have the highest rank as latent constructs (higher explained variance), but the lowest average value observed among students (lower mean scores) (Figure 1). Therefore, any initiative that seeks to improve BILA levels in students should consider these three constructs on evaluation-ethics, searching-using, and technological processing of the information a priority.

\section{About the sources of variability}

The results confirm that, also from a motivational perspective, there is a need for "situating information literacy in the disciplines" (Farrell and Badke, 2015). In this regard, we have found some motivational deficits, mainly concerning the students of English Studies. They show the lowest mean scores and the greatest number of significant -not due to chance- differences in comparison with the students of the other degrees. Translation \& Interpreting students are in an intermediate position, and those on Education provide the highest mean scores and a lower number of differences. If we try to account for the presence of non-random differences between the degrees, the difficulties in finding a satisfactory explanation for this should be acknowledged, due to the fact that there are no curricular or instructional data that allow a coherent interpretation. Undoubtedly, the absence of IL as an academic subject within their curricula is not a minor issue, even if they have some subjects that include aspects related to IL. That marginal presence of IL is higher in the degree of Education, and lower in that of English Studies. Probably, here lies the most reasonable explanation for these non-random differences, which are less when that IL presence, although marginal, is greater. Ultimately, the integration of IL in different higher education curricula still requires greater institutional commitment for it to really become a reality. 
This circumstance hinders a satisfying data interpretation. Meanwhile, when undertaking any BILA's motivational action for the degrees participating in this study, students of English Studies should be a priority.

From the results, a clear pattern of BILA's perceptions emerges in terms of course and gender. Regarding course, junior students unexpectedly offer higher scores than senior ones, even though logic may make us think otherwise. These significant differences focus on the factors of evaluation-ethics and dissemination of information, the most affected by variability (Table 4). The results are relatively understandable if some circumstances around this group of students are considered: the absence of IL in the curriculum; senior students are closer to professional work; their lack of motivation and uncertainty about their working future; and an excessive workload in their last university year. All these factors may contribute to the above-mentioned results. For gender, non-random differences in technological processing and dissemination factors emerge, with higher scores for women. However, the interpretation of this circumstance is not our priority in this study and would be the subject of future work.

\section{Some suggestions on BILA's enhancement}

Maybee and Flierl (2016: 3) propose a creative and reflective engagement with information: "motivational concepts and models have been used to suggest ways of creating information literacy instruction." Our suggestion here centers on designing awareness modules about BILA, specific to each of the six underlying factors. The contents of each module would be closely related to the abilities that make up the corresponding factor. The priority would correspond to the factor with the greatest weight, referring to competencies in the evaluation and ethics of information, followed by that of searching for and using information and that of technical processing. Due to the fact that these three factors obtained the lowest-rated abilities (Figure 1), our efforts ought to focus on them. As for abilities, those with the lowest mean scores and the 
greatest number of significant differences should become a priority. Inspired in these factors and abilities, the following three awareness modules are proposed (Table 5).

Module

Evaluation and ethics

Searching and use
On the importance of

Updating of information

Quality assessment of information

Plagiarism and the use of information

Terminology

Automated catalogues

Informal electronic sources of information

Database managers

Bibliographic reference managers

Statistical programs and spreadsheets

Information search strategies

Table 5. Modules and issues on BILA's awareness.

The content of these motivational modules should not be only instructional. The main goal to achieve is to trigger student interest. To encourage and engage students, content should be enjoyable and fun. In this regard, the inclusion of games gamification- would be quite suitable. The benefits of using gamified learning, an increasing trend in the last few years, are various: "improved student-engagement, motivation, confidence, attitude, perceived learning, and performance" (Subhash and Cudney, 2018: 205). Drawing is also increasingly used as a resource for IL learning: "learning information literacy through drawing encourages students to think and speak about information literacy" (Brier and Lebbin, 2015: 49). In any case, the most appropriate agents for the design of these BILA awareness modules would be the 
academic librarians, in close collaboration with the teaching staff of each subject. As Bury (2016: 241) states, "faculty placed emphasis on two main elements when defining IL: the ability to access information [...] and the ability to evaluate information and its sources critically." Precisely these two skills are included in the above-mentioned factors. Each module could be transformed into the corresponding one-shot face-toface session. It could also be disseminated online, by means of tutorials, training pills, and even by means of drawings, as this "encourages students to think and speak about information literacy in terms of a social activity that is complex, interpretative and creative" (Brier and Lebbin, 2015: 49).

\section{Conclusions and implications for further research}

Although the available literature does recognize the importance of IL abilities as tools for learning, there are no specific studies on the importance given by students. This work aims to be a fruitful contribution to the literature on IL since it enriches the knowledge about one facet of motivation, that on belief in importance.

From a degree perspective, the sample of students participating in this research -English Studies, Translation \& Interpreting, and Education- is rather homogeneous in terms of BILA's levels, though some significant differences emerge. These are higher in the case of students of English Studies. This circumstance, added to their lowest mean scores, call for motivational support. In this regard, an improvised objective, emerging along with this research, has been to raise awareness of the importance of embedding IL into the various syllabi. This drawback has prevented us from deriving deeper conclusions. We believe that the presence of a subject on IL in the involved degrees would reduce the number of significant differences.

Students' average levels of BILA have proved to be acceptable, but improvable. However, the deep structure uncovered could contribute to the motivational progress of students in terms of their BILA levels. In any case, this factor reduction may ease the 
planning and instruction processes about IL. Enhancement initiatives should take into account the six underlying factors; mainly, the three with the greatest weight: evaluation-ethics, searching-using, and technological processing of the information. These can be considered as a guide for the design of awareness modules on BILA's. Such modules could be implemented in the corresponding face-to-face sessions, or through online multimedia awareness kits, including drawing, games, and all kind of graphic-interactive resources. The coordinated work of both librarians and teaching faculty should address these awareness tasks, at the frontier of IL and learning, in the pursuit of enhancing students' holistic learning. In sum, a better understanding of the factors and variability about BILA could contribute to encourage, engage, and enhance students' learning status.

\section{Acknowledgements}

This study is part of the Spanish Research Program I+D+i (Research, Development \& Innovation), through the project 'Information competencies assessment of Spanish university students in the field of Social Sciences' (EDU 2011-29290). The authors are grateful to the teaching faculty colleagues who encouraged students to complete the questionnaire, and to the students of the sample. 
Annex. IL-HUMASS self-assessment questionnaire

\begin{tabular}{|c|c|c|c|}
\hline With regard to ... & \begin{tabular}{|l|} 
Belief-in- \\
importance
\end{tabular} & Self-efficacy & $\begin{array}{l}\text { Source of } \\
\text { learning }\end{array}$ \\
\hline COMPETENCIES-ABILITIES & $\begin{array}{l}\text { Low High } \\
123456789\end{array}$ & $\begin{array}{l}\text { Low High } \\
123456789\end{array}$ & $\begin{array}{l}\text { Cl Class } \\
\text { Co Courses } \\
\text { L Library } \\
\text { S Self-learning } \\
\text { O Others } \\
\end{array}$ \\
\hline \multicolumn{4}{|l|}{ INFORMATION SEARCH } \\
\hline \multicolumn{4}{|l|}{ 1. Using printed sources of information (books, papers, etc.) } \\
\hline \multicolumn{4}{|l|}{ 2. Entering and use automated catalogues } \\
\hline \multicolumn{4}{|c|}{ 3. Consulting and using electronic sources of primary information (journals, etc.) } \\
\hline \multicolumn{4}{|l|}{ 4. Using electronic sources of secondary information (databases, etc.) } \\
\hline \multicolumn{4}{|l|}{ 5. Knowing the terminology of your subject } \\
\hline \multicolumn{4}{|c|}{$\begin{array}{l}\text { 6. Searching for and retrieving Internet information (advanced searches, } \\
\text { directories, portals, ) }\end{array}$} \\
\hline \multicolumn{4}{|c|}{ 7. Using informal electronic sources of information (blogs, discussion lists, etc.) } \\
\hline \multicolumn{4}{|c|}{ 8. Knowing information search strategies (descriptors, Boolean operators, etc.) } \\
\hline \multicolumn{4}{|l|}{ INFORMATION EVALUATION } \\
\hline \multicolumn{4}{|l|}{ 9. Assessing the quality of information resources } \\
\hline \multicolumn{4}{|l|}{ 10. Recognizing the author's ideas within the text } \\
\hline \multicolumn{4}{|c|}{$\begin{array}{l}\text { 11. Knowing the typology of scientific information sources (thesis, proceedings, } \\
\text { etc.) }\end{array}$} \\
\hline \multicolumn{4}{|l|}{ 12. Determining whether an information resource is updated } \\
\hline \multicolumn{4}{|c|}{ 13. Knowing the most relevant authors and institutions within your subject area } \\
\hline \multicolumn{4}{|l|}{ INFORMATION PROCESSING } \\
\hline \multicolumn{4}{|l|}{ 14. Schematizing and abstracting information } \\
\hline \multicolumn{4}{|l|}{ 15. Recognizing text structure } \\
\hline \multicolumn{4}{|l|}{ 16. Using database managers (Access, MySQL, etc.) } \\
\hline \multicolumn{4}{|c|}{ 17. Using bibliographic reference managers (Endnote, Reference Manager, etc.) } \\
\hline \multicolumn{4}{|l|}{ 18. Handling statistical programs and spreadsheets (SPSS, Excel, etc.) } \\
\hline \multicolumn{4}{|l|}{ 19. Installing computer programs } \\
\hline \multicolumn{4}{|l|}{ INFORMATION COMMUNICATION AND DIFFUSION } \\
\hline \multicolumn{4}{|l|}{ 20. Communicating in public } \\
\hline \multicolumn{4}{|l|}{ 21. Communicating in other languages } \\
\hline \multicolumn{4}{|l|}{ 22. Writing a document (report, academic work, etc.) } \\
\hline \multicolumn{4}{|l|}{ 23. Knowing the code of ethics in your academic/professional field } \\
\hline \multicolumn{4}{|l|}{ 24. Knowing the laws on the use of information and intellectual property } \\
\hline \multicolumn{4}{|l|}{ 25. Creating academic presentations (PowerPoint, etc.) } \\
\hline 26. Disseminating information on the Internet (webs, blogs, etc.) & & & \\
\hline
\end{tabular}




\section{References}

ACRL (2000), Information Literacy Competency Standards for Higher Education, http://www.ala.org/acrl/standards/informationliteracycompetency $\quad$ (accessed 7 March 2020).

ACRL (2013), Working Group on Intersections of Scholarly Communication and Information. "Intersections of Scholarly Communication and Information Literacy", available

at: http://www.ala.org/acrl/sites/ala.org.acrl/files/content/publications/whitepapers/Inte rsections.pdf (accessed 7 March 2020).

ACRL (2016), Framework for Information Literacy for Higher Education, http://www.ala.org/acrl/standards/ilframework (accessed 7 March 2020).

Baier, S. T., Gonzales, S. M. and Sawilowsky, S. S. (2019), "Classroom Learning Communities' Impact on Students in Developmental Courses", Journal of Developmental Education, Vol. 42 No. 3, pp. 2-28.

Brier, D. J. and Lebbin, V. (2015), "Learning Information Literacy through Drawing", Reference Services Review, Vol. 43 No. 1, pp. 45-67.

Budd, J. M. (2006), "Toward a Practical and Normative Ethics for Librarianship", Library Quarterly, Vol. 76 No. 3, pp. 251-269.

Bury, S. (2011), "Faculty Attitudes, Perceptions and Experiences of Information Literacy: A Study across Multiple Disciplines at York University, Canada", Journal of Information Literacy, Vol. 5 No. 1, pp. 45-64.

Bury, S. (2016), "Learning from Faculty Voices on Information Literacy: Opportunities 
and Challenges for Undergraduate Information Literacy Education", Reference Services Review, Vol. 44 No. 3, pp. 237-252.

Carbo, T. and Almagno, S. (2001), "Information Ethics: The Duty, Privilege and Challenge of Educating Information Professionals," Library Trends, Vol. 49 No. 3, pp. $510-518$.

Davis-Kahl, S. (2012), "Engaging undergraduates in scholarly communication”, College \& Research Libraries News, Vol. 73 No. 4, pp. 212-222.

Davis-Kahl, S. and Hensley, M.K. (2013), Common ground at the nexus of information literacy and scholarly communication, available at: www.ala.org/acrl/sites/ala.org.acrl/files/content/publications/booksanddigitalresour ces/digital/commonground_oa.pdf (accessed 18 February 2020).

DeCoster, J. (1998), "Overview of Factor Analysis", available at: https://www.researchgate.net/publication/255620387_Overview_of_Factor_Analys is (accessed 9 March 2020).

Ding, R. and Ma, F. (2013), "Assessment of University Student Web Searching Competency by a Task-Based Online Test”, The Electronic Library, Vol. 31 No. 3, pp. $359-375$.

Fallis, D. (2007), "Information Ethics for Twenty-First Century Library Professionals", Library Hi Tech, Vol. 25 No. 1, pp. 23-36.

Farrell, R. and Badke, W. (2015), "Situating Information Literacy in the Disciplines: A Practical and Systematic Approach for Academic Librarians", Reference Services Review, Vol. 43 No. 2, pp. 319-340.

Floridi, L. (2013), The Ethics of Information, Oxford University Press, Oxford. 
Garcia-Marco, F.J. (2017), "The relevance of communicative competence in the context of information literacy programs", in Sales, D. and Pinto, M. (Eds), Pathways into Information Literacy and Communities of Practice, Elsevier, Cambridge, pp. 135-166.

Grafstein, A. (2002), "A Discipline-Based Approach to Information Literacy", The Journal of Academic Librarianship, Vol. 28 No. 4, pp. 197-204.

Gross, M. and Latham, D. (2008), "Self-Views of Information-Seeking Skills: Undergraduates' Understanding of What It Means to Be Information Literate." 2007 OCLC/ALISE Research Grant Report Published Electronically by OCLC Research, available at: http://worldcat.org/oclc/317880111/viewonline (accessed 9 March 2020).

Gross, M. and Latham, D. (2012), "What's skill got to do with it?: Information literacy skills and self-views of ability among first-year college students", Journal of the American Society for Information Science and Technology, Vol. 63 No. 3, pp. 574583.

Guglietti, M. (2015), "Exploring students' articulation of value in a social research methods class: Towards a phenomenography of value making", Teaching and Learning Inquiry, Vol. 3 No. 2, pp. 3-17.

Harlen, W. and Crick, R.D. (2003), "Testing and motivation for learning", Assessment in Education: Principles, Policy and Practice, Vol. 10 No. 2, pp. 169-207.

Hjørland, B. (2012), "Methods for Evaluating Information Sources: An Annotated Catalogue", Journal of Information Science, Vol. 38 No. 3, pp. 258-268.

Holliday, W. and Fagerheim, B.A. (2006), "Integrating Information Literacy with a Sequenced English Composition Curriculum", Portal: Libraries and the Academy, 
Vol. 6 No. 2, pp. 169-184.

Jones, W. (2007), "Personal Information Management", Annual Review of Information Science and Technology, Vol. 41 No. 1, pp. 453-504.

Keselman, H. J., Huberty, C. J., Lix, L., Olejnik, S., Cribbie, R. A., Donahue, B., Kowalchuk, R. K., Lowman, L. L., Petoskey, M. D., Keselman, J. C. and Levin, J. R. (1998), "Statistical practices of educational researchers: An analysis of their ANOVA, MANOVA, and ANCOVA analyses", Review of Educational Research, Vol. 68 No. 3, pp. 350-386.

Koehler, W. C. and Pemberton, J. M. (2000), "A Search for Core Values: Towards a Model Code of Ethics for Information Professionals", Journal of Information Ethics, Vol. 9 No. 1, pp. 26-54.

Kraiger, K., Ford, J. K. and Salas, E. (1993), "Application of Cognitive, Skill-Based, and Affective Theories of Learning Outcomes to New Methods of Training Evaluation", Journal of Applied Psychology, Vol. 78 No. 2, pp. 311-328.

Kuglitsch, R, Z. (2015), "Teaching for Transfer: Reconciling the Framework with Disciplinary Information Literacy", Portal: Libraries and the Academy, Vol. 15 No. 3, pp. 457-470.

Kuhlthau, C. C. (1991), "Inside the Search Process: Information Seeking from the User's Perspective", Journal of the American Society for Information Science and Technology, Vol. 42 No. 5, pp. 361-371.

Law, K.M.Y., Lee, V.C.S. and Yu, Y.T. (2010), "Learning motivation in e-learning facilitated computer programming courses", Computers and Education, Vol. 55 No. 1 , pp. $218-228$.

Leichner, N., Peter, J., Mayer, A. K. and Krampen, G. (2014), "Assessing Information 
Literacy Programmes Using Information Search Tasks", Journal of Information Literacy, Vol. 8 No. 1, pp. 3-20.

Lim, K. M. and Huan, V. S. L. (2017), "In focus: The role of education studies in teacher education", in Tan O.S., Liu W.C. and Low E.L. (Eds.), Teacher Education in the 21st Century, Springer, Singapore, pp. 77-106.

Limberg, L., Alexandersson, M., Lantz-Andersson, A. and Folkesson, L. (2008), "What Matters? Shaping Meaningful Learning through Teaching Information Literacy", Libri, Vol. 58 No. 2, pp. 82-91.

Linnenbrink, E. and Pintrich, P. (2002), "Motivation as an enabler for academic success", School Psychology Review, Vol. 31 No. 3, pp. 313-327.

Liu, C. J. and Yang, S. C. (2012), "Applying the Practical Inquiry Model to Investigate the Quality of Students' Online Discourse in an Information Ethics Course Based on Bloom's Teaching Goal and Bird's 3C Model", Computers and Education, Vol. 59 No. 2, pp. $466-480$.

Mai, J. E. (2013), "The Quality and Qualities of Information”, Journal of the American Society for Information Science and Technology, Vol. 64 No. 4, pp. 675-688.

Malliari, A., Korobili, S. and Togia, A. (2012), "IT Self-Efficacy and Computer Competence of LIS Students", The Electronic Library, Vol. 30 No. 5, pp. 608-622.

Markauskaite, L. (2007), “Exploring the Structure of Trainee Teachers' ICT Literacy: The Main Components of, and Relationships between, General Cognitive and Technical Capabilities", Educational Technology Research and Development, Vol. 55 No. 6 , pp. $547-572$.

Massey, G. and Ehrensberger-Dow, M. (2011), "Investigating information literacy: A growing priority in translation studies", Across Languages and Cultures, Vol. 12 
No. 2, pp. 193-211.

Maybee, C. and Flierl, M. (2016), "Motivating learners through information literacy", Libraries Faculty and Staff Scholarship and Research, Paper 150, pp. 698-707.

McClure, R. and Clink, K. (2009), "How Do You Know That?: An Investigation of Student Research Practices in the Digital Age," Portal: Libraries and the Academy, Vol. 9 No. 1, pp. 115-132.

Metzger, M. J. (2007), "Making Sense of Credibility on the Web: Models for Evaluating Online Information and Recommendations for Future Research", Journal of the American Society for Information Science and Technology, Vol. 58 No. 13, pp. 2078-2091.

Mills, L.A., Knezek, G. and Khaddage, F. (2014), “Information Seeking, Information Sharing, and going mobile: Three bridges to informal learning", Computers in Human Behavior, Vol. 32, pp. 324-334.

Oakleaf, M., Millet, M. S. and Kraus, L. (2011), "All Together Now : Getting Faculty, Administrators, and Staff Engaged in Information Literacy Assessment", Portal: Libraries and the Academy, Vol. 11 No. 3, pp. 831-852.

Paul, R. W. (2013), "Ethics without Indoctrination", available at: https://www.google.com/url?sa=t\&rct=j\&q=\&esrc=s\&source=web\&cd=4\&ved=2ah UKEwipkpGIwovoAhV_DmMBHT1bB0YQFjADegQIBhAB\&url=https\%3A\%2F\%2F pdfs.semanticscholar.org\%2F8c8d\%2F74f6dda59fceb584c66cba091604371c56af .pdf\&usg=AOvVaw0szxgipPw24thB36WDZWLA (accessed 27 January 2020).

Petrides, K. V. (2011), “An Application of Belief-Importance Theory with Reference to Trait Emotional Intelligence, Mood, and Somatic Complaints", Scandinavian Journal of Psychology, Vol. 52 No. 2, pp. 161-167. 
Pinto, M. (2010), "Design of the IL-HUMASS survey on information literacy in higher education: A self-assessment approach", Journal of Information Science, Vol. 36 No. 1 , pp. 86-103.

Pinto, M. (2011), "An Approach to the Internal Facet of Information Literacy Using the IL-HUMASS Survey", Journal of Academic Librarianship, Vol. 37 No. 2, pp. 145154.

Pinto, M. and Sales, D. (2010), “Insights into translation students' information literacy using the IL-HUMASS survey", Journal of Information Science, Vol. 36 No. 5, pp. 618-630.

Pintrich, P.R. (2004), "A conceptual framework for assessing motivation and selfregulated learning in college students", Educational Psychology Review, Vol. 16 No. 4 , pp. 385-407.

Rich, M. (2008), "Millennial Students and Technology Choices for Information Searching", The Electronic Journal of Business Research Methods, Vol. 6 No. 1, pp. 73-76.

Rieh, S. Y., Collins-Thompson, K., Hansen, P. and Lee, H.J. (2016), "Towards Searching as a Learning Process: A Review of Current Perspectives and Future Directions", Journal of Information Science, Vol. 42 No. 1, pp. 19-34.

Riehle, C. F. and Weiner, S. A. (2013), "High-Impact Educational Practices: An Exploration of the Role of Information Literacy", College and Undergraduate $\begin{array}{llllll}\text { Libraries, } & \text { Vol. } & 20 & \text { No. } & 2, & \text { pp. }\end{array}$ https://doi.org/10.1080/10691316.2013.789658

Rockman, I.F. (2002), "Strengthening Connections Between Information Literacy, General Education, and Assessment Efforts", Library Trends, Vol. 51 No. 2, pp. 
$185-198$.

Rosman, T., Peter, J., Mayer, A. K. and Krampen, G. (2018), "Conceptions of scientific knowledge influence learning of academic skills: epistemic beliefs and the efficacy of information literacy instruction", Studies in Higher Education, Vol. 43 No. 1, pp. 96-113.

Ross, M., Perkins, H. and Bodey, K. (2016), "Academic motivation and information literacy self-efficacy: The importance of a simple desire to know", Library and Information Science Research, Vol. 38 No. 1, pp. 2-9.

Saeger, K. J. (2014), "The Development of Critical Thinking Skills in Undergraduate Students", available at: https://www.semanticscholar.org/paper/The-Developmentof-Critical-Thinking-Skills-in-

Saeger/58cccdc3d346a7987a31469b159172a6a9c9a621 (accessed 3 February 2020).

Samek, T. (2010), "Teaching Information Ethics in Higher Education: A Crash Course in Academic Labour", International Review of Information Ethics, Vol. 14, pp. 4-9.

Savolainen, R. (2009), "Information Use and Information Processing: Comparison of Conceptualizations", Journal of Documentation, Vol. 65 No. 2, pp. 187-207.

Savolainen, R. (2018), "Berrypicking and Information Foraging: Comparison of Two Theoretical Frameworks for Studying Exploratory Search", Journal of Information Science, Vol. 44 No. 5, pp. 580-593.

Schield, M. (2004), "Information Literacy, Statistical Literacy and Data Literacy", IASSIST Quarterly, No. 6, pp. 6-11.

Seamans, N. H. (2002), "Student Perceptions of Information Literacy: Insights for Librarians", Reference Services Review, Vol. 30 No. 2, pp. 112-123. 
Subhash Reddy, B., Krishnamurthy, M. and Asundi, A. Y. (2018), "Information Use, User, User Needs and Seeking Behaviour: A Review", DESIDOC Journal of Library and Information Technology, Vol. 38 No. 2, pp. 82-87.

Subhash, S. and Cudney, E. A. (2018), "Gamified learning in higher education: A systematic review of the literature", Computers in Human Behavior, Vol. 87, pp. 192-206. https://doi.org/10.1016/j.chb.2018.05.028

Swenson, J., Young, C.A., McGrail, E., Rozema, R. and Whitin, P. (2006), "Extending the conversation: New Technologies, New Literacies, and English Education", English Education, Vol. 38 No. 4, pp. 351-369.

Taylor, A. (2001), "A Brief Introduction to Factor Analysis", Journal of Chemical Information and Modeling, Vol. 53, pp. 1-12.

UNESCO (2015), Rethinking Education: Towards a Global Common Good?, UNESCO, Paris.

Webber, S., Boon, S. and Johnston, B. (2005), "A comparison of UK academics' conceptions of information literacy in two disciplines: English and Marketing", Library \& Information Research, Vol. 29 No. 93, pp. 4-15.

Wilson, T. (2008), "The Information User: Past, Present and Future", Journal of Information Science, Vol. 34 No. 4, pp. 457-464.

Yong, A. G. and Pearce, S. (2013), "A Beginner's Guide to Factor Analysis: Focusing on Exploratory Factor Analysis", Tutorials in Quantitative Methods for Psychology, Vol. 9 No. 2, pp. 79-94.

Zylka, J. (2012), “Analyzing ICT Literacy of German Teachers : Focusing Age and Gender Issues as Well as Identifying Knowledge Levels." Proceedings of the 20th International Conference on Computers in Education, pp. 777-781. 